\title{
The Effects of Head Teachers' Leadership Styles on the Teacher Performance in Selected Mission and Public Secondary Schools of Muchinga Province- Zambia
}

\begin{abstract}
Maseka Godwin $^{1^{*}}$, Rachel Mabuku Kabeta ${ }^{2}$
Zambia

*Corresponding Author: Maseka Godwin, Zambia

Abstract: This paper discusses the effect of the Headteachers' leadership styles on Teacher performance in selected Mission and Public Secondary schools in Muchinga Province of Zambia. The sample size was 207. The study adopted a descriptive study design and a qualitative approach by engaging various stakeholders individually and in groups through in-depth interviews and focus group discussions. Simple random sampling was used to select the public secondary schools and the mission schools were selected purposive sampling because there were only two mission secondary schools. The study revealed that there is a relationship between head teachers' leadership style and teachers' performance in a given institution. The research further revealed that, headteachers in the selected public secondary schools were found to be using two leadership styles mainly to manage their schools. The two leadership styles are democratic and autocratic. On the other hand, the findings revealed that mission secondary schools use a wide range of leadership styles among them, democratic, transformational, and of course autocratic in certain instances. The study further revealed that performance of both teachers and learners was very good in mission schools as compared to that in selected public secondary schools. The study recommends that headteachers' leadership styles needed to be improved upon through capacity buildings, recommending them for further studies in Leadership and Management and also encouraging educational learning tours among schools in order to appreciate good practices that may transform teaching and learning. It further recommends that, for any headteacher to be appointed to the position head teacher, one needed to have under gone training in Education leadership and Management.
\end{abstract}

Keywords: Head teacher, Leadership styles, Teacher Performance, Public Secondary Schools, Mission Schools

\section{INTRODUCTION}

Leadership is considered as key in any given institution and effective practices of leadership are reported to have a positive relationship which leads to increased and improved organizational effectiveness and performance (Bass, 2006). It must be appreciated that leaders are good at inspiring the action and vision, which can positively influence and accelerate the process of exchange of ideas and knowledge According to Mbobola (2013) in a comparative study conducted on the effectiveness of trained headteachers with those who were untrained found that there were still higher percentages of headteachers that exhibited poor managerial skills.

Studies on teachers' performance in Zambia have largely focused on teachers' classroom practices, overlooking the potential influence of school leadership at different levels of our education system. Mwanza (2004) observed that, school leaders too, play a critical role in education since they are the ones who guide the teaching and learning processes. The intensified pressure on academic achievement has motivated education researchers as well as practitioners to focus more on school factors affecting both the teachers and pupils not to perform better (Mwanza, 2004).

The Ministry of General Education (MOGE), through the National Education Policy document (MOE, 1996), identified the important roles and responsibilities headteachers play in bringing about quality teaching and learning.

Kabeta et al (2015) further states that headteachers affect the teaching and learning process in the way they relate and offer leadership to teachers. The study further advises that head teachers need to be 
instructional leaders if the quality of teaching and learning has to improve. Day et al (2000) in his research findings from different countries and different schools revealed that effective leadership is related to school effectiveness and improvement. It's estimated that, schools that are effective and have the capacity to improve are led by headteachers who made a significant and measureable contribution to the effectiveness of their staff. According to Bass (2006), when decision making is perceived by teachers as collegial, cooperative, consultative and providing teaching and learning resources, the performance is usually expected to be excellent and to expected standards.

Research on school leaders in Denmark, Scotland, England and Australia by Macbeth (1998), identified a number of characteristics of effective leaders as those who work along their colleagues, respect teachers' autonomy, protecting them from extraneous demands and motivating them in different ways. It's in the same context that Kabeta et al (2015) associates effective instructional leadership with the quality of learning and teaching in schools. She further went on to state that the role of headteachers as instructional leaders is critical in the performance of teachers and learners.

The conducive school learning environment constitutes many factors among them, the nature of teachers' available, availability of financial and material resources, quality of leadership available and above all the nature of students to be taught. When these factors are in place, guided by qualified leadership, excellent teachers' performance is eminent. The leadership style employed by a given leader plays a pivotal role in quality teaching and learning. According to Mahadevan (2012):

“... Leadership is a powerful enabler that can leverage an organization to great heights, fame and credible position among the stakeholders. On the other hand, if the quality of leadership is bad, the same organization will experience a downward slide leading to the eventual destruction."

\subsection{Statement of the Problem}

The Ministry of General Education, in Zambia's National Policy Document on education "Educating our Future" of 1996 identifies the vital role that the school head must play in pursuit of excellence and quality in schools. Research shows that one of the factors that can influence the quality of teaching and learning in schools is the nature of leadership. Harris et al (2003) indicated that the most important single factor in the success of the schools is the quality of leadership of the head. Fullan (2001) also supports this when he states that increasingly, research has been associating school leadership with the quality of learning and teaching, the motivation of teachers and the ethos of the school.Despite these assertions not so much is said of the effect of the head teacher's leadership style on how teachers teach and there does not seem to be a study that was done in Muchinga Province of Zambia to establish the relationship between head teachers' leadership styles and the performance of teachers. This study therefore endeavored to do so.

\subsection{Purpose}

The purpose of the study was to establish the effect of headteachers' leadership styles on teacher performance in selected mission and public secondary schools in Muchinga Province of Zambia.

\subsection{Research Objectives}

- To find out the leadership styles used by the head teachers in the selected Mission and Public secondary schools in Muchinga Province.

- To establish whether the leadership styles of head teachers affect teachers' performance in the selected Mission and Public secondary schools.

\subsection{Research Questions}

- What type of leadership styles do head teachers in selected Mission and Public secondary schools use in Muchinga Province?

- What is the relationship between headteachers' leadership styles and teachers' performance in the selected Mission and Public secondary schools?

\subsection{Theoretical Framework}

\subsubsection{The Study Was Guided by Taylor's Motivation Theory-Scientific Management}

This was one of the first theories of motivation in the workplace which aimed at boosting productivity in a team. Taylor's Scientific Management theory attempts to find the most efficient way of 
performing any job. The goal was to find this 'one best way' of doing things as efficiently as possible. This theory outlined about three things in relation to workers; Managers should break down each employee's job into more manageable, bite-sized tasks, training should be given so that all employees perform their tasks in a standard way and that workers should be paid according to how much they produced. Taylor's theory is based on managers telling employees what to do; it is closely related to an autocratic leadership style. It focuses on collaboration between management and employees.

\subsection{Significance of the Study}

The study may provide the policy makers and other education stakeholders in the Ministry of General Education to examine the strengths and weaknesses of leadership styles used by headteachers in Mission and Public secondary schools. Such awareness may enable them to revisit the policies and come up with effective programmes that may positively impact the Ministry.

\section{LITERATURE REVIEW}

Literature presents various definitions of leadership and these definitions are quite diverse. Researchers usually define leadership according to their individual perspectives and what interests them.(Yukl, 2002).This definition includes the assumption that involves a process where intentional influence is exerted by one person over other people to guide, structure and facilitate activities and relationships in a group or organization.

Bass (2006) states that leadership is considered as key issue in any given institution and effective practices of leadership are reported to have a positive relationship with increased and improved organizational effectiveness and performance!

Leaders are supposed to be good at inspiring the action and vision, which can positively influence and accelerate the process of exchange of ideas and knowledge among the workers in a given working environment (Cole, 2000). Understanding the influence of different types of leaders on performance of team members is considered critical as it is directly related with the job performance of the employees. It's therefore very important for the team leader in this case the headteacher, to understand the different types of leadership styles to apply since the behaviour of the team members and subordinates is highly influenced by the leader of the institution.

Provision of direct assistance to teachers, group development, professional development, curriculum development, and action research activities are essential to the realization of pedagogical effectiveness. This is possible, with an effective quality leader who fully appreciates what leadership and management entails at a place of work.

\subsection{Leadership Styles}

Adeyemi (2006) described leadership style as a pattern of behaviour used by a leader in an attempt to influence group members to make decisions regarding the mission, strategy and operations of the group activities. Ezeuwa (2005) sees it as the act of influencing people so that they strive willingly and enthusiastically towards the accomplishment of goals. A leader needs to work with people, to influence them and direct them towards the achievement of organizational goals. According to Abwalla (2014), the manner in which the leader performs the roles and directs the affairs of the organization is referred to as his or her leadership style. Leadership style is therefore the way a person leads. Okumbe, (1998) defines leadership style as particular behaviours applied by a leader to motivate subordinates to achieve the objectives of the organization. The role of a head teacher in an organization is cardinal; he among other roles: manage, motivate personnel and provide leadership (Daresh, 2002). Therefore, the leadership style that one adopts to run the organization will affect the performance of teachers as positively or negatively. There are various leadership styles such as Autocratic, Democratic, Laissez-faire, Transformational and Transactional among others.

\subsection{Conceptual Framework}

Leadership is very important in an organization and literature has revealed that leadership is defined differently by various scholars. Leadership is defined as a process of influencing people towards achieving a particular objective. This study sought to establish the effects of head teachers' leadership styles on teacher performance and also to find out how this will consequently affect pupil performance. 
The Effects of Head Teachers' Leadership Styles on the Teacher Performance in Selected Mission and Public Secondary Schools of Muchinga Province- Zambia

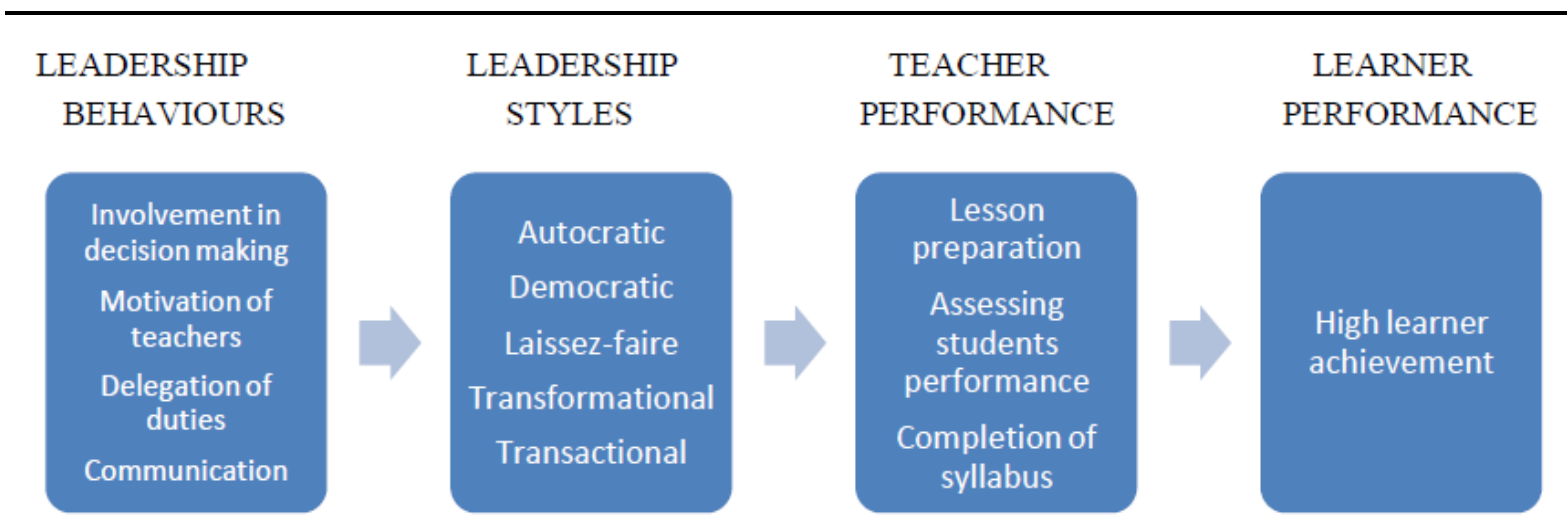

Source: Adopted from Onen (2010) Leadership styles and employee performance and some additions and modifications by author: 2019

\section{Methodology}

\subsection{Research Design}

The study used a descriptive research design which employed both quantitative and qualitative research methods.

\subsection{Research Sample and Sampling Procedures}

The study had a total of 207 participants which included four head teachers, eighty teachers, forty parents, twenty District Education Standards officers and sixty pupils (15 from each school). The public secondary schools in the study were selected using simple random sampling while purposive sampling was used to select the mission schools. The head teachers, heads of department, parents and education officials were selected using purposive sampling while the rest of the participants it was by using random sampling. The selected schools were coded as school A, B, C and D.

\subsection{Research Instruments, Data Collection Procedures and Data Analysis}

The instruments that were used for data collection were questionnaires and interviews. In this study, data was also collected through interviews in a face-to-face interaction between the interviewer and the interviewees by using structured interview schedule and also focus group discussions. The data was analyzed by using Microsoft excel and thematically.

\subsection{Ethical Considerations}

Ethical considerations were taken into account such as seeking permission from relevant authorities such as Mulungushi University and from the Ministry of Education and Provincial Education Offices. Issues of respondent's confidentiality and other basic research conventions were taken into consideration.

\section{FINDINGS AND DISCUSSION}

\subsection{To Find Out the Leadership Styles Used by the Head Teachers in the Selected Mission and Public Secondary Schools}

The study findings revealed that, all the participants in this study acknowledged that democratic, transformational, autocratic and transactional are some of the common leadership styles used in the selected secondary schools. Further that the type of leadership styles that were commonly used were the democratic autocratic leadership style though it also came out that the democratic style was more common in mission schools while in public schools the head teachers were more autocratic. According to Bass and Bass (2006), democratic leadership style is a leadership style in which the leader include one or more employees in the decision making process of the organization. However, the leader maintains the final decision. Head teachers who participated in this study considered themselves to be more democratic while the views of the teachers and pupils were that the head teachers used the autocratic leadership style more especially in the public secondary schools. $87.5 \%$ of teachers in mission schools showed that their head teachers used the democratic leadership style more, while only $12.5 \%$ said their head teachers were autocratic. In the public secondary schools, $60 \%$ of the teachers stated that their head teachers were democratic while $40 \%$ said they were autocratic. This 
is a type of leadership which is characterized by individual control over all decisions and there is very little input from the group members. It gives full authority to the leader. According to Yukl (2002), autocratic leaders tend to have the following characteristics: They do not consult members of the organization in the decision making process, leaders set all the policies and the leader predetermines the methods of work and determines how the duties of the subordinates.

It was clear from the qualitative findings in this study that under such a leadership style, teachers do not work freely and their performance is affected. From the qualitative data received from the Public secondary schools, the information is that the headteachers mostly apply autocratic leadership styles as the mode of managing the institutions. From the data collected, headteachers use this type of leadership style as a means to induce fear as a means to consolidating their authority. The more teachers feel intimidated the more the performance gets affected negatively. According to Mbiti (2014) the more teachers get scared of management at a working place, the more they tend to develop defensive mechanisms there by resulting into poor attitude towards work. Once this situation is entrenched in the workers, the performance starts to get affected negatively.

In Mission secondary schools, the findings of the study showed that all stake holders are involved in the management of the schools though the final decisions is made by the headteacher. The fact that all stakeholders are involved in the decision making process at school level clearly shows the applicability of democratic principles.

The study further revealed that headteachers in Mission schools also used transformational leadership style where they led as role models as compared to those in public secondary schools. Burns (1978) states that, transformational leadership style helps the leader and the follower to advance to a higher level of performance due to induced motivation by the leader. But Burns further stated that, the transformational approach in the leader creates significant changes in the life of the organization. This was reflected in this study from the findings on the qualitative data.

\subsection{To Establish Whether the Head Teachers' Leadership Styles Affect Teacher Performance in the Selected Mission And Public Secondary Schools}

The study also focused on whether the head teachers' leadership style had an effect on teachers' performance and consequently the academic performance of learners. The findings of the study revealed that, all the 20 heads of department and teachers who took part in the study agreed in total that the leadership styles of head teachers influenced the performance of teachers which also affects the academic performance of the learners.

The qualitative data in this study revealed that Mission schools performed better than Public secondary schools. The examination results from the selected learning institutions clearly showed the difference in performance of the pupils which the participants in the study attributed to the different leadership styles used by head teachers in Mission and Public secondary schools.

Figures Below Show the Grade 9 And 12 Results for the Selected Schools

\begin{tabular}{|l|l|l|}
\hline \multicolumn{1}{|c|}{ Year } & School & \\
\hline \multirow{5}{*}{2016} & A & 70 \\
\cline { 2 - 3 } & B & 100 \\
\cline { 2 - 3 } & C & 85 \\
\cline { 2 - 3 } & D & 100 \\
\hline 2017 & A & 77 \\
\cline { 2 - 3 } & B & 98 \\
\cline { 2 - 3 } & C & 75 \\
\cline { 2 - 3 } & D & 100 \\
\hline \multirow{3}{*}{2018} & A & 73 \\
\cline { 2 - 3 } & B & 100 \\
\cline { 2 - 3 } & C & 80 \\
\cline { 2 - 3 } & D & 100 \\
\hline
\end{tabular}

\begin{tabular}{|c|lc|cc|}
\hline Year & \multicolumn{2}{|c|}{ Schools } & \multicolumn{1}{c|}{ Performance in Grade 9(\%) } \\
\hline \multirow{2}{*}{2016} & $\mathrm{~A}$ & 63 & \\
\cline { 2 - 5 } & $\mathrm{B}$ & 96 & \\
\hline
\end{tabular}


The Effects of Head Teachers' Leadership Styles on the Teacher Performance in Selected Mission and Public Secondary Schools of Muchinga Province- Zambia

\begin{tabular}{|l|l|l|}
\hline \multirow{2}{*}{} & C & 68 \\
\cline { 2 - 3 } & D & 100 \\
\hline \multirow{3}{*}{2017} & A & 58 \\
\cline { 2 - 3 } & B & 95 \\
\cline { 2 - 3 } & C & 77 \\
\cline { 2 - 3 } & D & 98 \\
\hline \multirow{2}{2018}{} & A & 71 \\
\cline { 2 - 3 } & B & 98 \\
\cline { 2 - 3 } & C & 68 \\
\cline { 2 - 3 } & D & 100 \\
\hline
\end{tabular}

\section{SOURCE: EXAMINATIONS COUNCIL OF ZAMBIA}

The learning points as regards the qualitative data collected from the distinguished institutions were;

- The performance of pupils in the Mission secondary schools was very good and impressive while the performance from Public secondary schools was lower than that of the mission schools. The contributing factors to this excellent performance were attributed to sound leadership styles employed by the school managers in Mission secondary schools which affected the teachers positively. According to Kondalkar (2006), management of human behaviour and channeling it into correct direction is very important if results are to be produced. Application of motivational theories, art of leadership and skill of redesigning jobs and modification to organizational structure facilitates positive work environment leading to increased job satisfaction of employees. Every organization should provide enough incentive in the form of intrinsic and extrinsic stimuli.

- The findings of the study showed that Mission schools have revolving fund schemes that help the teachers to get soft loans and other incentives. Such initiatives not only motivate teachers but also allow teachers to go an extra mile in their job commitment and delivery.

- The findings further revealed that parents are more involved in fund raising ventures in mission schools than in public schools; and that the funds raised were used prudently to procure teaching and learning materials and contributed to the provision of incentives to the teachers. This it was learned make the teachers in mission schools to be motivated, work harder and produce good results. According to Bennell et al (2007) states that teacher motivation is critically depended on effective leadership and management skills, in particular at school level. If the systems and structures set up to manage and support teachers are dysfunctional, then teachers are likely to lose the focus. It is therefore the quality of leadership and styles applied that matter if meaningful known targets of an organizational change are to be attained.

- The study further revealed from observations by the researcher that the teachers in the two Mission secondary schools did have ample time to concentrate on teaching than focusing their efforts on looking for extra sources of income and as such quality time was devoted to preparations and teaching. It was observed that the teachers in public secondary schools were not available sometimes and their classes were not attended to.

- In the Public secondary schools, the findings from the qualitative data revealed that teachers devote very little time to teaching and preparations. Due to lack of interactions between the head teachers and teachers attributed to the autocratic type of leadership style, there seemed to be not much supervision over the teaching and learning. This scenario compromised the performance of learners in Public secondary schools. According to koldalker (2006), democratic and transformational leadership is practiced when leaders intellectually stimulate the subordinates, excites, arouses and inspire them to perform beyond their expectations by providing a new vision, and the capacity in the teachers to appreciate what they are engaged in. A good leader therefore should have intelligence, social maturity, inner motivation achievement orientation, and lastly human relation's attitude at the place of work. These values make the leader function to standards expected of a leader.

- Yukl (2010) observed that a favorable relationship and increased referent power for the leader made it easier to influence subordinates to carry out a request. Democratic leadership styles positively influences teachers towards excellent performance due to mutual appreciations of 
workers at a place of work. The leadership styles employed by the leader can either draw the teachers closer or far from the working station there by influencing the performance of the workers either positively or negatively. This was very clear from the findings of this study.

\section{CONCLUSIONS AND IMPLICATIONS}

The study concluded that the common leadership styles used by the four head teachers who participated in this study were democratic also known as participative, autocratic and transformational leadership. However, there were differences in the way the head teachers applied the leadership styles with public secondary schools inclined more to the autocratic leadership style while mission schools used the democratic leadership style more. Further that head teachers in mission schools also used the transformational leadership style with stress on morals and values. The study concluded too that the head teachers' leadership style affected teacher performance either positively or negatively and this consequently had effect on the performance of learners.

\section{RECOMMENDATIONS}

Based on the findings, the study recommends that the Ministry of Education should intensify training programmes for teachers and head teachers in Education Management and Leadership in order to build the capacity of school leaders. Further that the Ministry of Education should review its appointment criteria for heads of departments, deputy head teachers and head teachers so that only those who are trained in Education Management should be appointed.

\section{AREAS FOR FURTHER RESEARCH}

The study was conducted in one province with four schools only; therefore a similar study can be done at National Level in order for more generalization of results.

\section{REFERENCES}

[1] Abwalla, J (2014) The Principal's Leadership Styles and Teacher Performance in General Secondary Schools of Gambella Regional State. A Master's Thesis

[2] Adeyemi, T.O (2010). "Principals" leadership styles and teachers' job performance in senior secondary schools on ondo state, Nigeria. Journal of Educational Administration and policy studies 2(6), 83-91

[3] Ali, M.S., (2011). Head teacher's perceptions and practices of school leadership in private secondary schools in Ekiti state Nigeria. March, 2013, Vol.2, No.2.

[4] Ampaire. J. and Namusonge, G. (2015). Influence of headteacher's Leadership style on secondart school Student's Performance: a case of Meru District, Tanzania. Jomo Kenyatta University.

[5] Basu.R. (1994). Public Administration: Concepts and Theories. New Delhi. Sterling Publishers Private Limited.

[6] Bennell, P. and Akyeampong, K. (2007). Teacher Motivation in sub - Sahara Africa and South Asia. Sussex University.

[7] Bass and Bass (2006),The Bass hand book of leadership: theory, research, and managerial applications, $4^{\text {th }}$ edition free press.

[8] Bryman, A. (2004). Social research Methods. New York: Oxford university Press Inc.

[9] Cohen, Louis, Manion, Lawrence and Morrison. (2009). Research Methods in Education London. Routledge falmer.

[10] Cole. G. A. (2000). Personnel and Human Resource Management; RR Donnelley, China.

[11] Crossman, A. (2015), Purposive Sample, http://sociology.about.com//od/Types-of-samples/a/I. Retrieved: 25/05/2015.

[12] Chafwa, F. (2012). Impact of management styles exhibited by school heads on staff performance in selected Government High schools in Kawambwa District of Luapula Province. Med Dissertation. University of Zambia.

[13] Creswell, J. W. (2009), Research Design, Qualitative, Quantitative and Mixed Method Approach, London: Sage Publication Ltd

[14] Daresh, J.C. (2002). What it means to be a Principal: Your Guide to Leadership; ERIC

[15] Edmonds, R.R. (1978). "Effective schools for urban Poor", Educational leadership; Vol. 37

[16] Eissa, A. Brown. D and Wiseman, A (2013). The effect of Principal leadership styles on School environment and outcome Kuwait. 
[17] Ezeuwa, L, (2005). Issues in Educational Management; Hipuks Additional Press, Enugu Nigeria.

[18] Fullan, M. (1995). The school as a learning organisation. Theory into Practical. 34 (4), 230-235

[19] Harris et al (2003), Improving Ineffective Departments in Secondary Schools: Strategies for Change and Development; Educational Mgt\& Admin 26 (3) 269- 278

[20] Kabeta. R. M, Manchishi, P.C and Akakandelwa, A. (2015). Instructional leadership and Its effect on the teaching and learning process: The case of Headteachers in selected Basic schools in Central province of Zambia. International journal of science and research ISSN (On line): 2319-7064, Volume 4 issue 4.

[21] Kasinga, S. K. (2010). Influence of Principals' Leadership on Public secondary school Teachers' level of Job Satisfaction in Nairobi Province. Unpublished M. Ed. Project, University of Nairobi.

[22] Kasonde, S.N. (2014). Writing a Research Proposal in Educational Research. Lusaka: UNZA Press.

[23] Kombo, D. K and Tromp, D.L.A. (2006). Proposal and Thesis Writing: An Introduction. Nairobi: Paulines Publications Africa.

[24] Mbiti, D.M., (2007). Foundation of school administration, oxford.

[25] Mbobola, A.M. (12013). A Comparative Study of the effects of the effectiveness of Trained Management Head teachers with Those Untrained: a study of selected Schools of Chongwe District. A dissertation Submitted to the University of Zambia; Unpublished.

[26] Ministry of General Education in focus (2017). Ministry of General Education Bulletin, HQ, Lusaka.

[27] Ministry of Education, (1996). Educating Our Future; National Policy on Education. Ministry of Education, Lusaka.

[28] Mwanza, P. (2004). Teacher Perception of school management practice and their influence On Teacher performance in selected high schools of Lusaka: Med.

[29] Mwape, K., (2013). A survey of head teacher's leadership and their effects of School Climate in Selected schools in Northern Province. M. Ed. Dissertation. Lusaka. University of Zambia

[30] Okumbe, J.A (1998) Educational Management: Theory and Practice; Nairobi University Press

[31] Obiwuru, T.C, Okwu, A.T and Akpa, V.O. (2011). Effects of leadership styles on organizational performance: A survey of selected small scale Enterprises in Ikosi ketu council Development Area of Lagos state of Nigeria. University of Lagos.

[32] Onen, D, (2010) Leadership Styles and Employee performance; Makerere University

[33] Yukl, G. (2010) Leadership in Organizations, $7^{\text {th }}$ Edition; NJ Pearson

\section{AUTHORS' BIOGRAPHY}

Godwin Maseka is a head teacher at Chinsali girls Secondary School; he holds a primary teachers' certificate, a secondary teacher's diploma. He also holds a Bachelor's degree with a major in Mathematics and Geography. He has just completed his Master's degree in Education Administration and Leadership at Mulungushi University in Kabwe.

Rachel Mabuku Kabeta holds a $\mathrm{PhD}$ (Education Administration), has 29 years teaching experience in secondary school, teacher training at college and university level. She specializes in teaching and research in Education Management, Administration and Leadership. She is currently a lecturer at Mulungushi University in the School of Education.

Citation: Maseka Godwin, Rachel Mabuku Kabeta. "The Effects of Head Teachers' Leadership Styles on the Teacher Performance in Selected Mission and Public Secondary Schools of Muchinga Province-Zambia". International Journal of Humanities Social Sciences and Education (IJHSSE), vol. 6, no.9, 2019, pp. 158-165. doi: http://dx.doi.org/10.20431/2349-0381.0609018.

Copyright: (C) 2019 Authors. This is an open-access article distributed under the terms of the Creative Commons Attribution License, which permits unrestricted use, distribution, and reproduction in any medium, provided the original author and source are credited. 